\title{
Early developmental stages in spore germination of Laurencia sp. I (Ceramiales, Rhodophyta) from Kyaikkhami and Setse coastal areas, Mon state
}

\begin{abstract}
Liberated tetraspores and carpospores of mature plants of Laurencia sp. 1 collected from Kyaikkhami (Lat. $16^{\circ} 05^{\prime} \mathrm{N}$, Long. $97^{\circ} 34^{\prime} \mathrm{E}$ ) and Setse (Lat. $15^{\circ} 52^{\prime} \mathrm{N}$, Long. $97^{\circ} 8^{\prime} \mathrm{E}$ ) coastal areas had been cultured at temperature $25^{\circ} \mathrm{C}$ under $16 \mathrm{~L}: 8 \mathrm{D}$ photoperiod using PES medium in $20 \%$ salinity. The development of tetrasporelings in the laboratory cultures stopped after 30 days, whereas that of carposporelings stopped after 20 day. Both tetraspores and carpospores germinate into bipolar sporelings with erect shoot and colourless rhizoidal filaments in Laurencia sp. 1. Moreover, the germination pattern of tetraspores was similar with that of carpospores. However, the growth rate of carposporelings was slower than tetrasporelings. In the present study, the germling stages of both tetraspore and carpospore showed the Fucus type of the germination pattern. The developmental stages of tetraspore and carpospore germination of Laurencia sp. 1 were briefly described.
\end{abstract}

Volume 9 Issue 6 - 2020

Soe Pa Pa Kyaw, San Tha Tun, U Soe Htun
Department of Marine Science, Mawlamyine University, Myanmar

Correspondence: Soe Pa Pa Kyaw, Associate professor, Department of Marine Science, Mawlamyine University, Myanmar, Email soepapakyaw.marine@gmail.com

Received: December 19,2020 | Published: December 31, 2020

Keywords: carpospores, germination, kyaikkhami, laboratory culture, laurencia $s p$. 1, setse, tetraspores

\section{Introduction}

The genus Laurencia is a small to medium-sized red algae, under the order Ceramiales and family Rhodomelaceae. The species of Laurencia are mainly found in warm waters, and often tropical and subtropical parts of the world. ${ }^{1}$ Laurencia spp. grow in a variety of habitats such as, in tide pools, on reef flats, in protected or exposed locations, and on stones, rocks, dead coral, and other seaweeds, of intertidal and subtidal zones. These species are characterized as 'turf-forming'. They can dominate the hard substrata in some marine communities. Fish and invertebrates may graze on Laurencia species, and these Laurencia-herbivore interactions are controversial ecological topic as cited in McDermid. ${ }^{2}$

The red algal, Laurencia is a great scientific and commercial potential, as cited in McDermid. ${ }^{2}$ Species of Laurencia are known to produce diverse, unique, halogenated secondary metabolites as cited in Masuda et al.. ${ }^{3}$ The secondary metabolite chemistry can provide criteria for taxonomy in Laurencia. ${ }^{4}$ Spore germination has been studied in a number of species like Odonthalia floccosa ${ }^{5}$ from the order Ceramiales.

Nyo Nyo Tun ${ }^{6}$ investigated the chemical compositions of Laurencia $s p$. from Setse and Kyaikkhami areas. She demonstrated Laurencia sp. contained $0.63-0.77 \%$ protein, $0.33-1.34 \%$ lipid, $2.0-5.0 \%$ crude fibre, $0.0037-0.0653 \%$ iodine, $17.35-35.21 \%$ ash, $11.5-17.9 \%$ moisture, $11.1-20.5 \%$ sulphate and $21.23-33.29 \%$ carbohydrate. In addition, the elemental compositions (such as $\mathrm{Ca}, \mathrm{Fe}, \mathrm{K}, \mathrm{Mg}, \mathrm{Mn}, \mathrm{Na}, \mathrm{Zn}, \mathrm{Cd}, \mathrm{Hg}$, and $\mathrm{Pb}$ ) of six species of red seaweeds: Acanthophora spicifera (M. Vhal) Boergesen, Catenella nipae Zanardini, Gracilaria caniliculata Sonder, G. verrucosa (Hudson) Papenfuss, Hydropuntia edulis (S.G Gmelin) Furgel \& Frediricq and Laurencia sp. In Laurencia sp., the content of $\mathrm{Ca}(4600 \mathrm{ppm}), \mathrm{K}(11819 \mathrm{ppm}), \mathrm{Mg}$ (5788ppm), Mn (953ppm), Na (7717ppm), Zn (81ppm), Cd (1.30ppm), Hg (1.10ppm), and $\mathrm{Pb}(0.60 \mathrm{ppm})$ were observed.?

In Myanmar, San Tha Tun ${ }^{8}$ studied the laboratory culture of the red alga, Laurencia sp. collected from Setse coastal areas. He also described the optimal growth of thallus and sporelings of Laurencia sp. under various environmental parameters such as salinity, temperature, light intensity, photoperiod and nutrients in the laboratory.

Soe $\mathrm{Pa} \mathrm{Pa} \mathrm{Kyaw}^{9}$ reexamined and identified the plants of Laurencia as Laurencia sp. 1, Laurencia sp. 2, L. pinnata Yamada and $L$. composita Yamada, using the specimens collected from the three Coastal Regions of Myanmar from 1969-2014. Moreover, the identification of Laurencia sp. 1, was described by Soe Pa Pa Kyaw and Soe-Htun. ${ }^{10,11}$ The objective of the present study is to observe early germination stages and spore germination pattern of Laurencia $s p .1$ under laboratory conditions.

\section{Materials and methods}

The specimens were collected from the upper intertidal zone of Setse (Lat. $15^{\circ} 52^{\prime} \mathrm{N}$, Long. $97^{\circ} 38^{\prime} \mathrm{E}$ ) and Kyaikkhami (Lat. $16^{\circ} 05^{\prime} \mathrm{N}$, Long. $97^{\circ} 34^{\prime} \mathrm{E}$ ), from June 2014 to September 2015. The collected plants were brought to the Phycological Research Laboratory in the Department of Marine Science, Mawlamyine University, Mawlamyine, in ice-boxes. In the laboratory, the fresh and healthy plants were thoroughly washed with painting brushes in the sterile seawater to remove epiphytes and some contaminants. For the culture experiments, seawater was filtered with What man No. 1 filter paper and then autoclaved.

For the spore (tetraspore and carpospore) germination, mature cystocarpic and tetrasporangial plants were used as seed materials. The fertile (tetrasporangial and cystocarpic) branchlets were cut and placed in petri dishes $(4 \mathrm{~cm} \times 2 \mathrm{~cm})$ containing sterilized seawater of $20 \%$ salinity at $25^{\circ} \mathrm{C}$ under $16: 8$ hours of light/dark cycle and light intensity of $\left(70-240 \mathrm{ftc}=15-50 \mu \mathrm{molm}^{-2} \mathrm{~s}^{-1}\right)$ in Gallenkamp Incubators (Volts 220/240, Hz 50, Cat No. INF 781-T). After 6-8 hours, spores were liberated and were transferred with capillary pipette to glass slides $(1 \mathrm{~cm} \times 1 \mathrm{~cm})$. The slides were inoculated inside the Petri-dishes containing $20 \mathrm{ml}$ of $20 \%$ salinity seawater with Provasoli's ${ }^{12}$ Enriched seawater (PES) medium (1968) and then the antibiotic stock solution was added to this medium. The medium was renewed every 2 days 
intervals for a week. The spores were examined under a compound microscope (Olympus 285872, Japan) every day. After examination, a slide was fixed in $4 \%$ formalin seawater every day. The diameter of liberated spores and germlings were measured using ocular meter In this study, culture experiments were repeated three times. Spore germination stages were photographed using a Panasonic (Lumix) DMC-TZ 15 digital camera and processed using Adobe Photoshop CS.

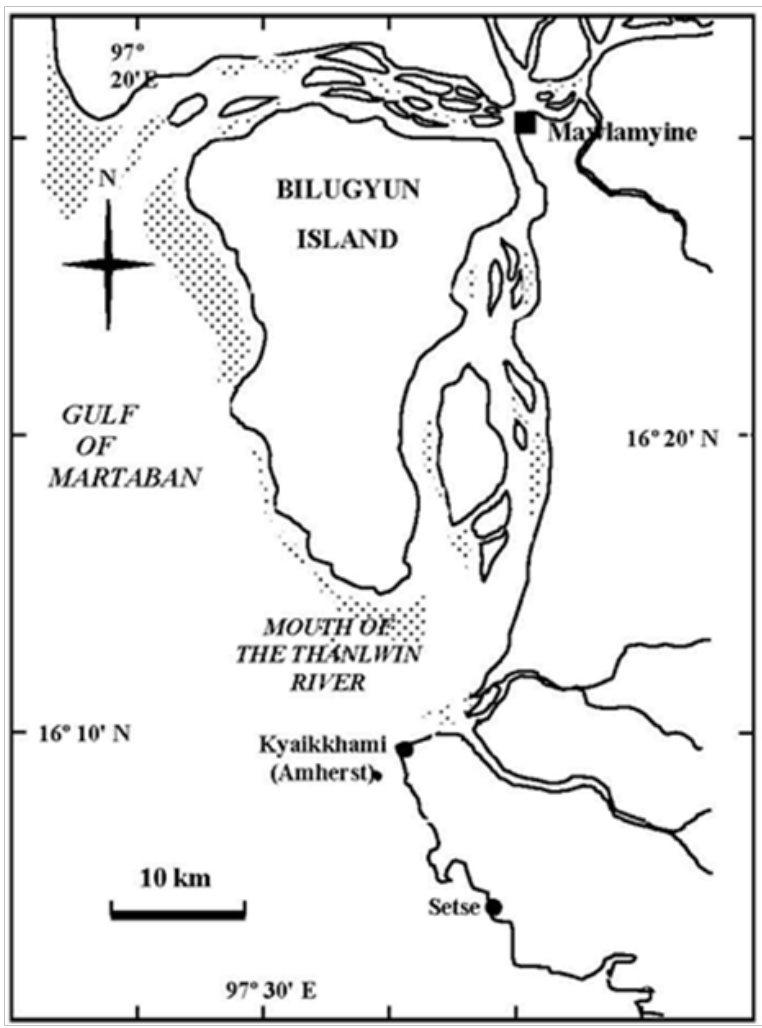

Figure I Map showing the collection sites of Laurencia sp. I

\section{Results and discussion}

\section{(a) A classification system of the genus Laurencia}

The present study basically follows the classification system of Saito and Womersley and Guiry and Guiry. 13,14

Phylum: Rhodophyta

Class: Florideophyceae

Order: Ceramiales

Family: Rhodomelaceae

Genus: $\quad$ Laurencia Lamouroux

Section: $\quad$ Laurencia

Species: $\quad$ Laurencia sp. 1

\section{(b) Morphological notes of field-collected plants, Laurencia sp.1}

Fronds, caespitose and prostrate (Figure 2), 3-11 cm in diameter, densely entangled with stoloniferous branches, reddish brown, rigid, and cartilaginous in texture, attached to the substratum by discoid holdfasts formed on main axes and secondary branches; main axes, terete with blunt tips terminate in a small depression; branches cylindrical, 2-12mm long, irregularly alternate. Plants grow on mud flat or on rocks covered with sand in the upper to lower intertidal zones. This species attached to the substratum by stoloniferous holdfast. It occurs in places exposed to wave action forming dense carpets. The plants can be found throughout the year. The luxuriant growth was found in early August to late October.

Tetrasporangial stichidia (Figure 3), formed on the apical portions of secondary branches and branchlets; simple or with 1-5 branches; cylindrical, $725-2000 \mu \mathrm{m}$ long and $500-700 \mu \mathrm{m}$ broad. In the carpogonial plant (Figure 4), the secondary branches and branchlets cylindrical when sterile, but these become broad with the development of the cystocarps. Cystocarps, single or in clusters (1-5 lobes) with one or more apical ostiole, borne laterally on branches (except first to fourth-order branches), broadly ovoid, slightly pointed at these apices; $570-1100 \mu \mathrm{m}$ long and $670-1800 \mu \mathrm{m}$ broad at maturity.

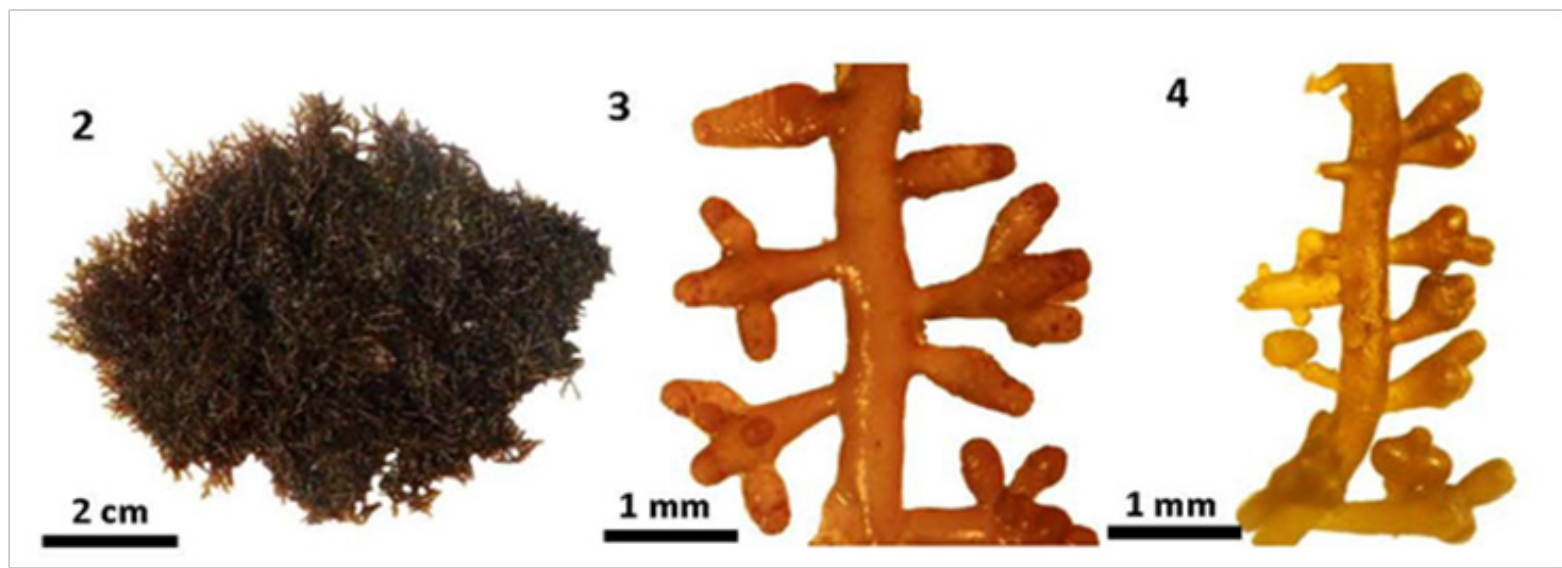

Figure 2-4 Field collected plant of Laurencia sp. I. (2). Habit of plant. (3) Part of Tetrasporangial plant. (4) Part of carpongonial plant.

(c) Early Developmental Stages in Spore germination of Laurencia sp. 1 in Laboratory Culture

\section{Germination of tetraspores}

The liberated tetraspores are spherical, measuring $55-57 \mu \mathrm{m}$ in diameter, and reddish brown in colour. Each spore begins to germinate after 24 hours. Tetraspores germinate into bipolar sporelings with erect shoot and colorless rhizoidal filaments. The first division is transverse and it forms a row of 2-3 cells. The sporeling reaches $60-$ $65 \mu \mathrm{m}$ in length after 2 days. The second division is transverse, and 
then it divides longitudinally into unequal cells. Tetraspore cells are large size and divided into 8-16 cells in 2-3 days and many celled stage in 4-11 days. The sporeling continues to grow about $200-800 \mu \mathrm{m}$ in length and form a multicellular structure. At 8-many celled stage, the rhizoidal filaments form from the basal part of the erect shoot. And also, the disc-shaped rhizoids are formed. The number of rhizoids in 7-30 days old sporelings is observed about two to five, and it reaches $188-350 \mu \mathrm{m}$ in length. Sometimes, secondary attachment rhizoids and small lateral branchlets are formed in 14-30 days. Trichoblasts are initiated from apical pits in 11 days. The development of sporelings in the laboratory cultures have been stopped after 30 days (Figure 5-16).

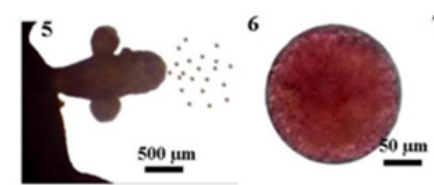

9

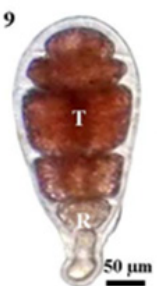

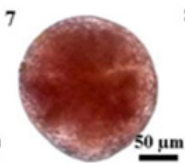
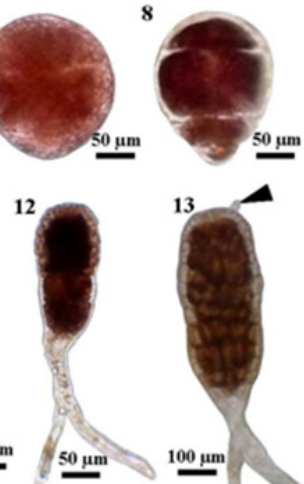
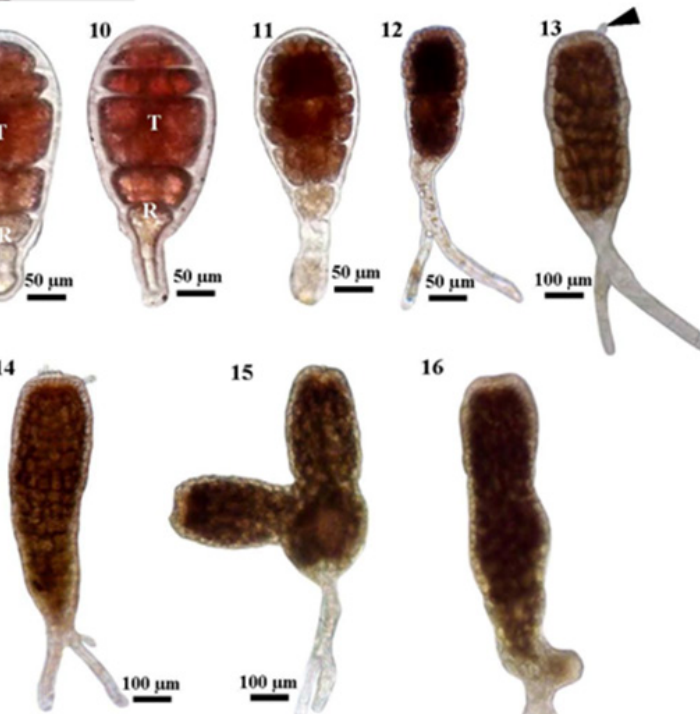

16

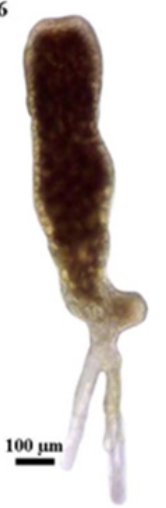

Figure 5-16 Tetraspores and their early development in Laurencia SP. I.(5) Liberation of Tetraspores from Tetrasporangia stichidia. (6) Released tetraspores, (7-8) Tetrasporeling with two to three unequa-celled stages with developed rhizoids after four to seven days. 13) Tetrasporeling produces trichoblast (arrowhead) after eleven days.( 14,I5) Tetrasporeling produces small lateral branchlet after twenty days. 16) Tetrasporeling shows developed rhizoids after thirty days.

\section{Germination of carpospores}

The liberated carpospores are spherical, measuring $60-65 \mu \mathrm{m}$ in diameter, and reddish brown in colour. Each spore begins to germinate after 24 hours. Carpospores germinate into bipolar sporelings with erect shoot and colorless rhizoidal filaments. The first division is transverse and it forms a row of 2-4 cells. The sporeling reaches $75-$ $100 \mu \mathrm{m}$ in length after 2 days. The second division is transverse, and then it divides longitudinally into unequal cells. Carpospore cells are small size and divided into many celled stage in 3-7 days. The sporeling continues to grow about $100-225 \mu \mathrm{m}$ in length and form a multicellular structure (Figure 17-25). At 4-many celled stage, the rhizoidal filaments form from the basal part of the erect shoot. The discshaped rhizoids are occasionally formed. The number of rhizoids in
4-20 days old sporelings is observed about two to seven, and it reaches $112-125 \mu \mathrm{m}$ in length. Sometimes, secondary attachment rhizoids and small lateral branchlets are formed in 14-20 days. Trichoblasts are initiated from apical pits in 14 days. The development of sporelings in the laboratory cultures have been stopped after 20 days.
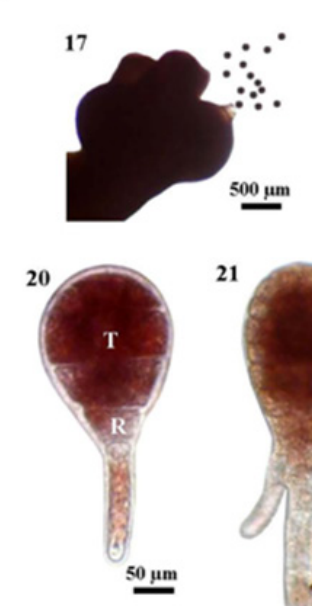

21

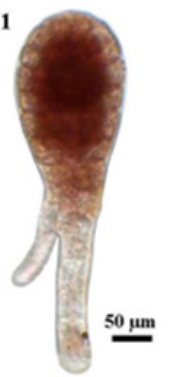

24

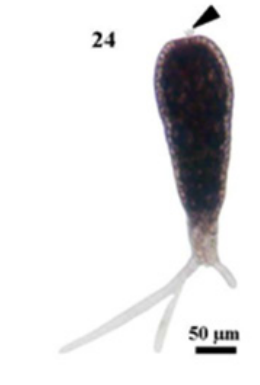

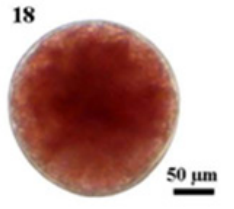

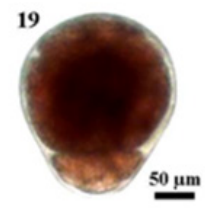

23

22
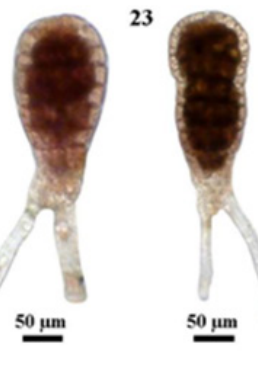

Figure 17-25 Carpospores and their early development in Laurencia sp. I. (I7) Carpospores from field collected plant. (18) Released carpospores. 19) Carposporeling with two unequal -celled stages formed after one day. (20) Carposporeling produce a thallus cell $(T)$ and a rhizoid cell $(R)$ after two days. (2I-23) Carposporeling formed several cell stages with developed rhizoids after three to seven days. (24) Carposporeling produces trichoblast (arrowed) after fourteen days. (25) Carposporeling shows many developed rhizoids after twenty days.

In spore germination of Laurencia sp.1, the germination pattern of tetraspores was similar to that of carpospores. The average diameter of liberated tetraspores and carpospores was 55-65 $\mu \mathrm{m}$. Each spore began to germinate after 24 hours. However, cell division of tetraspores and carpospores was different. Tetraspore cells was large size and divided into 8-16 cells in 2-3 days, but carpospore cells was small size and divided into 2-4 cells in 1-2 days. Thus, cell division of tetrasporelings was faster than cell division of carposporelings. The disc-shaped rhizoids, secondary attachment rhizoids and small lateral branchlets were formed in both sporelings. Trichoblasts were initiated from apical pits after 11 days in tetrasporelings and after 14 days in carposporelings.

The present study shows that the germination pattern of both tetraspores and carpospores in Laurencia sp. 1 was similar to the Fucus type germination pattern. ${ }^{15,16}$ In this type, the spores germinate into bipolar sporelings with erect shoot and colorless rhizoidal filaments. According to Figure 26, the growth rate of carpospores germination of Laurencia sp. 1 is slower than that of tetraspore germination. In the laboratory culture, tetrasporelings died after 30 days, but 
carposporelings died after 20 days. Figure 26 shows the comparison of the growth rate between the tetrasporelings and carposporelings in 20 days experimental period.

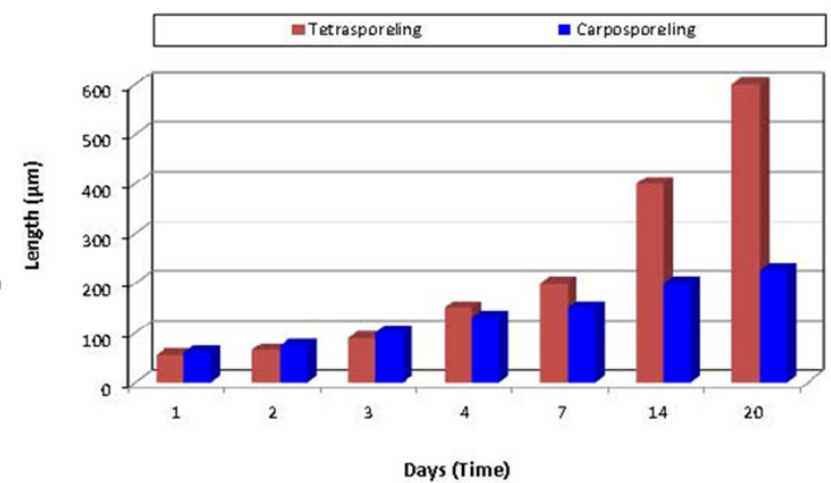

Figure 26 Average mean length of tetrasporelings and carposporelings of Laurencia sp. I after 20days culture periods.

San Tha Tun ${ }^{8}$ described the developmental pattern of tetrasporelings and carposporelings in Laurencia sp. are the same. Cho Cho Latt ${ }^{17}$ described the early developmental pattern of both tetraspores and carpospores germination in Caloglossa spp. which was similar to the Fucus type germination pattern. Likewise, Khin Khin Gyi and Khin Khin Gyi and Soe-Htun ${ }^{18-20}$ described the germlings of Bostrychia spp. showed the characteristic of bipolar spore germination pattern of the order Ceramiales.

\section{Conclusions}

Liberated tetraspores and carpospores of Laurencia $s p .1$ were cultured for the spore germination under the laboratory conditions. The plants of Laurencia sp. 1 abundantly grow along the intertidal zones of Setse and Kyaikkhami coastal areas in monsoon season. Spores of this species well developed in salinity $20 \%$. Field collected plants of Laurencia sp. 1 with tetrasporangial and cystocarps were selected, and then cultivated to study the early developmental stages of spore germination. The tetrasporelings increased in length and measuring a total length of up to $800 \mu \mathrm{m}$ after 30 days, however, the carposporelings increased in length up to $225 \mu \mathrm{m}$ after 20 days during the culture periods. The germination pattern of tetraspores was similar to that of carpospores. The germling stages of both tetraspores and carpospores show the Fucus type germination pattern. Therefore, the culture studies on spore germination may be needful to designate the biological species concept of Laurencia sp. 1 .

\section{Acknowledgements}

We are indebted to Dr. Aung Myat Kyaw Sein, Rector, and Dr. San San Aye, Pro-Rector, Mawlamyine University, for their supports and encouragement in this study. We are thankful to the late Dr. Min Thein, Director (Retd.) Microalga Biotechnology Department, Myanmar Pharmaceutical Factory (MPF), Yangon, Myanmar for his literature provided. Our special thanks go to Dr. Mya Kyawt Wai, Associate Professor (Head), Department of Marine Science, Sittwe University and Dr. Jar San and Dr. Sein Moh Moh Khaing, Lecturers, Department of Marine Science, Mawlamyine University for their valuable assistance throughout this study. We are thankful to U Ka Lay and Daw Pan Myint, Staffs of Aquaculture Research Centre, Setse, for their help in collecting specimens from the natural beds of Setse coastal areas.

\section{Funding}

None.

\section{Conflits of interest}

The author declares that there is no conflicts of interest.

\section{References}

1. Gil-Rodriguez MC, Haroun R. The genus Laurencia (Rhodomelaceae, Rhodophyta) in the Canary Islands. Courier Forsch.-Inst. Senckenberg. 1993;159:113-117.

2. Mc Dermid, K.J. Laurencia from the Hawaiian Islands: Key, annotated list, and distribution of the species. In: Abbott I.A. Editors, Taxonomy of economic seaweeds with reference to some Pacific and Caribbean species. California Sea Grant College Program, University of California. $1988 ; 2: 231-247$

3. Masuda M, Kogame A, Arisawa S, et al. Morphology and halogenated secondary metabolites of three Gran Canarian species of Laurencia (Ceramiales, Rhodophyta). Botanica Marina. 1988;41(6):265-277.

4. Masuda M, Abe T, Suzuki T. Morphological and chemotaxonomic studies on Laurencia composita and L. okamurae (Ceramiales, Rhodophyta). Phycologia. 1996;35(6):550-562.

5. Masuda M, Uwai S, Kogame K. Developmental morphology of Odonthalia floccosa (Ceramiales, Rhodophyta) in laboratory culture. Phycological Research. 1998;46(4):239-251.

6. Nyo Nyo Tun. Studies on the chemical composition of some Myanmar algae of Setse area, Thanbyuzayat Township, Mon State. Unpublished Master of Science Thesis. Department of Marine Science. Mawlamyine University. 1999.

7. War War Nwe, Myint Myint Cho. Study on the elemental compositions in some red seaweeds (Rhodophyta) from Kyaikkhami and Setse Coastal Areas. Mawlamyine University Research Journal. 2011;3(1):170-179.

8. San Tha Tun. Laboratory culture of the red algae, Laurencia sp. Unpublished M.Sc. Thesis. Department of Marine Science. Mawlamyine University. 1990.

9. Soe $\mathrm{Pa} \mathrm{Pa}$ Kyaw. Systematics of Laurencia complex (Ceramiales, Rhodophyta) of Myanmar. Unpublished Ph.D Thesis. Department of Marine Science, Mawlamyine University. 2014

10. Soe Pa Pa Kyaw, Soe-Htun U. Studies on the developmental morphology and life history in culture of Laurencia sp. 1 (Ceramiales, Rhodophyta) from Myanmar. Aquac Mar Biol. 2018;7(4):246-251.

11. Provasoli L. Media and prospects for the cultivation of marine algae. In: Watanabe A, Hattori A, editors, Cultures and collections of algae. Proc. U.S.-Japan Conf. Hakone, September 1966. Jap Soc Plant Physiol. $1968 ; 63-75$.

12. Soe $\mathrm{Pa} \mathrm{Pa}$ Kyaw, Soe-Htun U. Morphology and distribution of Laurencia sp. 1 (Ceramiales, Rhodophyta) from Myanmar. Aquac Mar Biol. 2019;8(6):190-196.

13. Saito Y, Womersley HBS. The southern Australian species of Laurencia (Ceramiales, Rhodophyta). Aust J Bot. 1974;22:815-874.

14. Guiry MD, Guiry GM. Algae Base. World-wide electronic publication, National University of Ireland, Galway. 2020.

15. McLachlan J. Effects of temperature and light on growth and development of embryos of Fucus edentatus and F. distichus spp. distichus. Can J Bot. 1974;52(5):943-951.

16. Bouget FY, Berger F, Brawnlee C. Position dependent control of cell fate in the Fucus embryo: role of intercellular communication. Development. 1998;125(11):1999-2008. 
17. Cho Cho Latt. Morphology and spore germination of the genus Caloglossa J. Agardh (Ceramiales, Rhodophyta) from Setse and Kyaikkhami Coastal areas. Department of Marine Science. Mawlamyine University. 2011.

18. Khin Khin Gyi. Morphology and spore germination of the genus Bostrychia Montagne (Ceramiales, Rhodophyta) from Setse and Kyaikkhami Coastal areas. Department of Marine Science. Mawlamyine University. 2011.
19. Khin Khin Gyi, Soe-Htun. U. The morphotaxonomy, phytogeographical distribution and culture studies of Bostrychia tenella (Lamouroux) J. Agardh from Setse and Kyaikkhami Coastal areas. Mawlamyine University Research Journal. 2014;6(1):128-142.

20. Khin Khin Gyi, Soe-Htun U. Systematics of the genus Bostrychia Montagne from Setse and Kyaikkhami I: B. radicans Montagne (Montagne) based on the morphology and development of sporelings in culture. Universities Research Journal. 2014. 6(3):1-22. 